\title{
The Social Enterprising Success : Study of Comparative Cases Between Cooperatives and Agricultural Enterprises
}

\author{
Majda EL AGY \\ Faculty of low, Economics and Social Sciences, Cadi Ayyad University, Marrakesh, Morocco \\ Correspondence : Faculty of low, Economics and Social Sciences, Marrakesh, Morocco.
}

\begin{abstract}
The social entrepreneurship is a recent and a bit explored discipline. This is the interest of the present research which aims to be exploratory. It is situated among the interpretative essays of social enterprising of success. To do this, we have opted for a qualitative approach based on semi-directive interviews carried out with entrepreneurs operating within the Moroccan agricultural sector. Results of the analysis of case studies show that enterprising success, according to the informants asked, is distinguished on a major point. This distinction, which is psychological, is the interest shown by the interviewers and interviewees respectively to the other (collective aspect) and to oneself. The results of this research allow better appreciation of the behaviour of social entrepreneurs. They are relevant to researchers, practitioners and involved parties. They are devoted to the regional and local development, by offering some points of reference which are more precise and can help them understand better this phenomenon.
\end{abstract}

Keywords: Social enterprising; Economic entrepreneurship; Social enterprising success; Agricultural cooperatives, Agricultural enterprises.

DOI: $10.7176 / \mathrm{EJBM} / 11-7-01$

Publication date:March $31^{\text {st }} 2019$

\section{Introduction}

The importance of enterprising success as a strategic objective is confronted with interpretive plurality. In fact, the absence of clarity of the conception of social enterprising success hinders seizing the steps of social entrepreneurs, as well as their strategy in the development as far as regional, national, and international markets are concerned.

No one can object to the importance of the enterprise company. However, it didn't arouse the interest of researchers engaged in the enterprising field. In this context, research on the success of enterprising focused on the economic and traditional success ( Sammut, 2001 ; Cheung \& Chow, 2006 ; Dahan, 2008; Filion, 2010 ; Zafir \& Fazilah, 2011), whereas few studies were interested in social enterprising success (Baron, 2000; Hähnel, 2011; Sharir \& Lerner, 2006). This few literature can be explained principally by the emergence of the notion of social enterprising (Cukier \& al., 2011 ; Letts \& al., 2003). Like all recent disciplines, the shape of social enterprising is still not well defined.

The aim of this research is to define and compare personal perceptions of social and economic entrepreneurs as far as enterprising success is concerned. Do the present entrepreneurs define enterprising success in the same way ? Do distinctions in perceptions exist between the ones and the others? These are the question we attempt to answer in this research.

The conceptualization of the notion of enterprising success seems essential in order to know better the personal perceptions of economic and social entrepreneurs in this domain. The possible differences are already a modest tentative to ameliorate the understanding of social enterprising outline. Also, the relatively new characteristic of this phenomenon justifies well the interest we hope to give in this present study.

\section{Theoretical framework}

The concept of the social entrepreneurship brings closer the meaning of Mair et Marti (2004) in two aspects:"entrepreneurship" and "social". If the facet entrepreneurship is determining in the understanding of the concept of social entrepreneurship, it is necessary to define what we mean by entrepreneurship. This preliminary definition allows the understanding of the difference between social and economic entrepreneurship.

\subsection{What is entrepreneurship?}

In spite of the absence of a standard and universal definition of entrepreneurship and entrepreneur, this discipline arouses a remarkable interest. Marchesnay $(1995 ;$ p.153) already resumes this report by underlining that « the notion of entrepreneur is one of the most controversial, full of meaning in the strategic analysis ».

Entrepreneurship can be approached depending on the positioning of the research (economist, manager, psychologist....). Also, many investigators have attempted to define and delimit the field of entrepreneurship. Without being exhaustive, we cite the contributions of Cantillon, say, Schumpeter and Bruyat (1993), of Filion (1997), of Shane and Venkataraman (2000), and most recently of Tunes and Fayolle (2006). The economists (Cantillan, Say, Schumpeter) distinguished two main figures of entrepreneurs, one as an activity organizer and the 
other as innovator (Fayolle, 2004a). Chronologically, Cantillon (1697-1734) identified three categories of actors : the owners, the farmers, and the entrepreneurs. The latters group together the merchants, the artisans, and the manufacturers, etc. For Cantillon, to anticipate the risks and to face the uncertain are the two traits which characterize the activity of the entrepreneur (Hernandez, 2001). Another economist, Say (1767-1832) was interested in the activities of the entrepreneurs that he defines as a coordinator of resources, and put him in the center of the economic process. According to say, the farmer, the manufacturer or the trader is also considered as an entrepreneur (Tounes \& Fayolle, 2006). Smith (1723-1790) joined the idea of Say by considering the entrepreneur as a capitalist.

Quantified as the father of the field of entrepreneurship in the sense of Filion (1997), Schumpeter (1883-1950) insists on the aspect of innovation of the entrepreneurs, and his participation in the economic development via innovation. Besides taking risks, innovation constitutes the principal characteristic of the entrepreneur according to Schumpeter (1883-1950). Only individuals who are able to innovate deserve the name of entrepreneur. The latter becomes the motor of technical progress.

Another approach to delimit the field of entrepreneurship borrows many ways. According to Bruyat (1993), entrepreneurship can be defined as : "The dialogic individual / creation of values » which is subscribed under dynamics of change. For Shane and Venkataraman (2000), it can be defined by the discovery and exploitation of opportunities.

Tounes \& Fayolle $(2006 ;$ p.26) think that « $[. .$.$] the entrepreneur is generally confused with the small$ enterprise. He is no longer heroic by the major innovations which shake society. He often creates his own job. He is close to his clients, his suppliers, his financiers and his local partners. He is included within a complex network of enterprises where he finds his source of innovation $»$.

From a sociological or psychological point of view, some authors attempt to define the entrepreneur in terms of personality features, motivations or behaviors. In his article "who is an entrepreneur ? Is the wrong question", Gartner (1988) asked these questions to know what differentiates the entrepreneur from the others. Based on research which describes the personality of entrepreneur realized by Cole, Gartner comes to the conclusion that many definitions of entrepreneur exist, but they don't permit the distinction between the entrepreneur and another individual. Also, he pinpointed two ways to approach the enterepreneur, who is the entrepreneur ? " The trait approach ") and what does the entrepreneur do ? ("The behavioral approach"). The trait approach rests on the part that the entrepreneur possesses some psychological characteristics which distinguish him from individuals who are not entrepreneurs. Whereas the approach by facts aims at putting into evidence the necessary competences for an entrepreneur in order to do well his enterprising activities. Gartner (1988), sustains that it is necessary to study more the behavior than the trait because it is richer in information and permits to define the activities exercised by the entrepreneur (Fayolle, 2004b). Danjou (2002), on the other hand stresses that both approaches can be complementary. The reading of these approaches allows the observation of the existence of a real difficulty to agree on a unique definition of entrepreneurship and entrepreneur.

\subsection{Economic entrepreneurship Vs Social entrepreneurship}

Even if the interest in social entrepreneurship knows a recent rise (Cukier et al., 2011), the phenomenon is not new, of course. Cantillon has already evoked the entrepreneur as a social actor. Dees and Anderson (2006) affirm that the emergence and evolution of social entrepreneurship are due to the creation of the American Foundation Ashoka which rests on the vision of « the school of social innovation », and the creation of the firm of consultants New Ventures which rests on the vision of « School of social enterprise ». These two schools of thought permit to enrich the global field of social entrepreneurship (Cukier et al., 2011).

Other researchers stress that social entrepreneurship is defined as « [...] a process linked to the discovery of occasions in order to create social richness and the organizational processes developed and used to achieve the desired objectives » (Brouard, 2006 ; p.3). On his part, Levesque (2002) made a distinction between three types of entrepreneurship private, collective and social. He defined the latter as a project which vise the enrichment and accomplishment of a community according to the social interests. In this way, these authors confirm that social entrepreneurship does not dwell a lot on the economic dimension, but focuses on the satisfaction of social needs. The seeking of benefits is just a means to serve the social mission in order to fund and assure the durability of the enterprise.

According Cukier et al. (2011) economic entrepreneurship is distinguished from social entrepreneurship. The first concentrates more on the creation of the richness considering its potential to energize the economic development, while the second seeks to make the world better and to generate the social capital. Brouard (2006), underlines that the principal distinction the social and economic entrepreneurship is the social mission to accomplish. Without the latter, there will be no social entrepreneurship. Within the same logic, relying on the works of the national center for social entrepreneurs (2001), we propose a synthetic table comparing the social and economic entrepreneurs according to diverse variables $(C f$. Table 1$)$. 
Table 1: Recapitulative comparison of types of entrepreneurs

\begin{tabular}{|l|l|l|}
\hline Variables & \multicolumn{1}{|c|}{ Social entrepreneurs } & Economic entrepreneurs \\
\hline Strengths & Collective experience & Financial gain (benefit) \\
\hline Focus & Development of capacities & Short Term \\
\hline Perspectives & Long term & No limit \\
\hline Extended & Limited by vision & $\begin{array}{l}\text { Profit is an aim } \\
\text { Distribution to shareholders }\end{array}$ \\
\hline Profits & $\begin{array}{l}\text { Profit is a means } \\
\text { Reinvestment }\end{array}$ & Personal actives and investors \\
\hline Risks & Actives of the organization, image and confidence & Face to an employer \\
\hline Autonomy & Face to donators & \\
\hline
\end{tabular}

Source : Brouard (2006; p.6)

To follow the tendencies of writings on "social entrepreneur" and "social entrepreneurship" Cukier et al. (2011) carried out an analysis of the content of five hundred sixty seven scientific articles, using standardized terms of research in many bibliographical Data base such as EBSCO, PROQUEST, etc. The results of their analysis show that the definitions are not all coherent and consensual. These notions still remain not well defined taking into account their complexity and ambiguity. This latter can be explained by the fact that the concept of social entrepreneurship associates two terms often judged contradictory.

\subsection{Enterprising success : what do we talk about?}

The definition of success is still ambiguous in the field of research on entrepreneurship. The defining tendencies lead to contradictory results. This contradiction is explained by the absence of a consensus on the notion of success. It is within this frame that the following question is subscribed : enterprising success : what do we talk about ?

Scrutinization of literature shows a strong conceptual heterogeneity. Each author conceives and analyses in his own way (Sammut, 1998) and depending on the mobilized theoretical approach (Smida \& khelil, 2008). A better understanding of this phenomenon consists on the clarification of success in order to understand more its measure indicators.

The concept of success was defined in different ways (Zafir \& Fazilah, 2011) and few authors define it clearly. Many authors were devoted to the defining exercise of the concept by assimilating it to the tangible elements such as growth, creation of personal wealth, profitability; durability as well as revenue (Amit Mac Crimmon et al., 2011) or to the combination of two parameters such as survival and growth (Lasch et al., 2005). On his part, Michaud (2003) proposes a model of five meanings of success which correspond to different individual profiles such as (1) intellectual sprinter (quest for intellectual intensity) ; (2) the marathonian (quest belonging identity) ; (3) career sprinter (quest for power) ; (4) Defeat sprinter (quest for realization) and (5) the pilgrim (quest for sense, engagement direct for a collective project). The author showed that success can involve two classifications: success for oneself and success in the other. Indeed, success is a dual concept which raises from both an objective subjective dimension. According to Bravo-Bouyssy (2004), subjective success or intrinsic success can be conceived of as the judgment the individual does with his achievement. Whereas, objective success or extrinsic success corresponds to the judgment done by the others on the professional accomplishments of the individual.

The preceding developments show clearly the difficulty to delimit precisely the concept of enterprising success. So, there is no consensual definition. However, a concrete understanding of success tempts to decline its measurement factors.

\subsection{Key factors of success}

There is a huge body of literature concerning key factors of the success of economic entrepreneurship. But, to our knowledge, research works on key factors of success relative to social entrepreneurship are few, and particularly in agricultural sector. The presentation of the existant literature on this topic is preliminary to tackle our issue.

Even if the model profile of a successful entrepreneur is difficult to delimit, nevertheless some forewarning features of enterprising success exist. A great debate and many interests concerning these factors are at stake (Pavlovich \& Corner, 2006), literature in this domain adopts a static vision. In this way it mobilizes particularly the individual factors of the entrepreneurs, such as the level of schooling (Nabi, 1999) and enterprising experience (Capron et al., 2009).

Other factors can equally have an effect in a significant way on the success of the entrepreneur such as age and gender (Lortie-Lussier \& Rinfret, 2005). Moreover, some works put into evidence that the matrimonial status could have a significant influence on enterprising success. According to them, Cheung and Chow (2006) find a positive relationship between the fact that the entrepreneur is married and enterprising success. Lasch et al. (2005), on the other hand, classify factors of success into three categories : ones which refer to the entrepreneur, his environment, and the organization. According to them, these three categories are not distinct, but are interrelated.

Literatures propose other useful factors. Also Filion \& Borges (2010a) remarked that networking is extremely 
important in the world of affairs. This finding is reinforced by Zafir and Fazilah (2011) for whom the success of the entrepreneurs is influenced by the support of the others, it can take two forms : a formal and informal support. The formal support is in the form of financial aid, technology, strategic partnership or industrial contact. These elements allow to the entrepreneurs to obtain new information (Carrier et al., 2004). Whereas the informal support may come from personal network (Levent, Masurel, \& Nijkamp, 2003). Besides, Zafir \& Fazilah (2011) mentioned that Chinese entrepreneurs from Hong Kong have excelled in their affairs because of the practice of "Familialism", which involves the role of ethnical belonging and territorial context.

Even though different recent works exist within this frame, works of Sammut (2001) brought a very interesting enlightenment on the topic. So, the author proposed four types of factors promoting the success of new enterprise. The latters depend on certain intrinsic characteristics if the entrepreneur (parents entrepreneurs, capacity of learning), of characteristic linked with the environment (market research; use of professionals...), of characteristics linked with financial resources (taking moderate risks, obtaining a capital in sufficient quantity), as well as those linked with the organization (specialization of employees, participation in decision making...). With regard to this, Filion and Borges (2010b) advance other factors : to know how to take action without skimping on too much when the suitable moment emerges, to know how to be surrounded, to know how to preserve a low level of indebtedness, to know how to adopt a frugal behavior which limits spending and to know how to be committed as a creator, etc.

Literature on this subject brings to the surface a big diversity of factors. Nevertheless, it seems that the key factors of the success of social enterprising are not accepted in unanimity by researchers. Cheung and Chow (2006), come to the conclusion according to which enterprising success can vary depending on the industries, people, places, and time.

Beyond the economic factors already mentioned, researches on factors of success of social enterprising are a bit studies in literature. The contribution of Sharir and Lerner (2006) identified eight key factors of success of social entrepreneurship. The latters were classified in this way in accordance with their value (1) « the entrepreneur's social network »; (2) «total dedication to the venture's success »; (3) « the capital base at the establishment stage »; (4) «the acceptance of the venture idea in the public discourse »; (5) « the composition of the venturing team, including the ratio of volunteers to salaried employees »; (6) « forming cooperation's in the public and non profit sectors in the long-term »; (7) « the ability of the service to stand the market test »; et (8) « the entrepreneurs' previous managerial experience $»$. Works on this topic are still in the embryonic stage and necessitate future researches which are in depth and rigorous.

\section{Research Method}

\subsection{Operating framework of the research}

Agricultural cooperatives constitue the basis of social economy (Bchini, 2012). According to this author, the cooperative is distinguished from the economic enterprise by its democratic character and its social purpose. Besides its social dimension, it is marked via its economic and financial dimension. According the ACL (International Cooperative Alliance), these cooperatives are characterized by their fundamental values such as mutual and personal responsibility, democracy, the taking charge, equality, and solidarity. For its members, they adhere to an ethical based on altruism, social responsibility, honesty, and transparency.

Within the frame of this research, the emphasis is put on agricultural cooperatives and particularly those of Argan oil situated in the Souss Massa Drâa Region. In Morocco, approximately $93 \%$ of these cooperatives are created by women. In fact, the creation of this type of cooperatives in the region had favorable consequences at the social level, particularly for rural women, by assuring classes of alphabetizing on one hand, and a decent income, on the other. This income permits to ameliorate their standard of living, and to become autonomous financially. The accent is also put on the agricultural enterprises situated in the same region, in order to highlight the principal similarities and dissimilarities between these two types of organizations.

\subsection{Method of collection of data}

In Morocco, there is no data base susceptible to provide necessary information in order to delimit the sample of the research. From this fact, a work of considerable prospection was necessary so that to find cases which correspond the most to the central question of the present research. So, the sample was identified further to the indications of people already asked, or more through acquaintances in the domain of affairs (snowball technique). During the first interview, a mutual confidence was established with the entrepreneur interviewed to the point that he gave us the coordinates of another entrepreneur who has created his enterprise or his cooperative within the same sector of activity. For the size of the sample, according to the exploratory characteristic of the research, we chose deliberately to carry out the research with six cases. A choice which is going to allow us to detect points of reference for future research which is larger and global. Moreover, the collection of data was done via individual semi-directive interviews in order to touch directly the individual and to make sure that the questions are completely understood. This tool is successful to seize the behaviors and preoccupations of the actors (Usunier $e t$ 
al., 1993).

Our guide is organized in two themes tackled during the interview. The first tackles general information relative to the entrepreneurs interviewed on their enterprises. The second theme deals with the signs of the success of enterprising, it is divided into two sub-groups such as the place of success in the vision of the entrepreneur and the factors of success linked with the creation of the enterprise.

\subsection{Techniques of analysis}

We used the following technique : Audio recording (dictaphone) and the note taking. The use of dictaphone permits us to preserve the integrality of the expressed opinions, making data exhaustive and discursive, without worrying about the risk to miss information (Thiétart, 1999). Concerning note taking, it allowed us to concentrate on the progress or the conduit of the interview (boast, listening, etc), thus, the interview « requires sagacity and vivacity from the researcher » (Baumard et al., $1999 ;$ p.236).

All the interviewees accepted to be recorded apart from one. The interviews made with the concerned persons were totally retranscribed by ourselves in order to analyze them correctly. The transcript allowed us to make later the coding of the empirical data, which was done through the software of qualitative analysis "QSR NVivo 9". In addition to that, we read and re-read our transcription of interviews many times to know which theme is related to which fact. Helped by the software, we proceeded to the decontextualization "coding" to emerge the extract from its context. After that, we proceeded to the recontextualization by reconstructing a new structure with the codified extracts that we used as support for final results.

The exploitation of these interviews was treated through to the method of cases. As it is stressed by Yin (1994) in the same sense, multiple case studies give generally a more solid basis for the construction of theories. Hence, as well specified by Gagnon (2005; p.13) « the researcher who considers to resort to case study, or any other qualitative method of research, should subscribe to the constructive perspective according to which society is not given, as positivists stress, but constructed via the relations established by individuals ». This method seems relevant because it is going to offer us the best understanding of the meaning of social enterprising success.

\section{Study Results}

The presentation of results is done in two stroke, of principal characteristics of our sample so that to go progressively towards results dealing with the central question of this research. These characteristics are synthesized in Table 2 and 3.

Table 2 : Description of agricultural cooperative studied

\begin{tabular}{|l|l|l|l|l|l|}
\hline Case & Age/gender & Status marital & Legal Form & Level of schooling & Number of adherents \\
\hline E1 & 33/ Men & Single & S.A.R.L & Professional Training & 6 \\
\hline E2 & 39/Men & Married & S.A.R.L & Baccalaureat & 4 \\
\hline E3 & 40/ Men & Married & S.A.R.L & Bachelor's degree & 8 \\
\hline
\end{tabular}

Table 3 : Descriptions of agricultural enterprises studied

\begin{tabular}{|l|l|l|l|l|l|}
\hline Case & Age/gender & Status marital & Legal Form & Level of schooling & Number of adherents \\
\hline E1 & 33/ Men & Single & S.A.R.L & Professional Training & 6 \\
\hline E2 & 39/ Men & Married & S.A.R.L & Baccalaureat & 4 \\
\hline
\end{tabular}

\subsection{Characteristics of the sample selected}

For the sake of confidentiality, identification of respondents will not be mentioned. This process will have no impact on the analysis of the cases. Table 2 and 3 show some important differences between the profiles of the interviewers and the interviewees.

Cooperatives studied are all situated in the province of Agadir Idaa Outanan and at the heart of the Argan forest, which reduces same the cost of raw material. The number of female adherents is between 50 and 60 . They are all married, and their age varies between 30 and 40. For schooling, their level is below Baccalaureate. The principal mission of adherents consists in crushing Argan nuts. These three cooperation commercialize a part of the production on the spot, the rest is done by the Economic Grouping Interest.

We note, according to table 3, that all the individuals interviewed are men, their age varies between 30 and 40 , and they have a level of schooling higher than the one of the founders (women) of the cooperative.

\subsection{Enterprising success : Proposition of definition by interviewers and interviewees}

Enterprising success: what do we talk about? The question asked at the beginning of that work finds a nuanced answer among interviewers and interviewees. In order to obtain a clearer reading, the principal results are presented in a synthetic way in table 4 . 
Table 4 : Conception of enterprising success

\begin{tabular}{|c|c|c|}
\hline Cases & Agricultural Cooperative & Agricultural Enterprise \\
\hline C1-E1 & $\begin{array}{l}\text { Development of the province } \\
\text { "To participate actively in the development of our } \\
\text { province» }\end{array}$ & $\begin{array}{l}\text { Growth } \\
\text { «It is the growth of my enterprise» }\end{array}$ \\
\hline C2-E2 & $\begin{array}{l}\text { To satisfy the needs of clients } \\
\text { " To satisfy the needs of our clients by offering them } \\
\text { a product of quality » }\end{array}$ & $\begin{array}{l}\text { Financial situation } \\
\text { «To have a good financial situation » }\end{array}$ \\
\hline C3-E3 & $\begin{array}{l}\text { To satisfy the needs of the adherents } \\
\text { " To satisfy the needs of adherent women by } \\
\text { ameliorating their standard of living " }\end{array}$ & $\begin{array}{l}\text { Achievement of goals } \\
\text { "To achieve the goals fixed at the creation of } \\
\text { the enterprise " }\end{array}$ \\
\hline
\end{tabular}

\subsection{Key Factors of Success}

The principal results are presented in a synthetic way in the following table 5

Table 5 : Key Factors of Success

\begin{tabular}{|c|c|c|}
\hline Cases & Agricultural Cooperative & Agricultural Enterprise \\
\hline C1-E1 & $\begin{array}{l}\text { External support } \\
\text { "The starting of the cooperative has been made possible thanks to the } \\
\text { back of a number of people (benefactors) and organization of economic } \\
\text { development present in the region Souss Massa Drâa, Agency of Social } \\
\text { Development, rural municipality, and the National Initiative for Human } \\
\text { Development [...] Without this, the cooperative could have encountered } \\
\text { many difficulties » }\end{array}$ & $\begin{array}{l}\text { Support external } \\
\text { "Success comes through } \\
\text { my relationship with the } \\
\text { others, I cannot achieve } \\
\text { it if I am alone in my } \\
\text { enterprise » }\end{array}$ \\
\hline C2-E2 & $\begin{array}{l}\text { Feeling of belonging } \\
\text { - Adherent women : [...] the work supplied for adherent women } \\
\text { provide them with a feeling of security, they feel perfectly at home in } \\
\text { the cooperative, they feel they are useful by participating in decisions. } \\
\text { Moreover, they apprecident the fact that they are close to their home } " \\
\text { - Clients : }[\ldots] \text { our clients consume our product, because of its best } \\
\text { quality. Add to this, they follow closely the evolution of our } \\
\text { cooperative and encourage it in difficult moments » }\end{array}$ & $\begin{array}{l}\text { Perseverance } \\
\text { «I invest enormously } \\
\text { time and effort in my } \\
\text { enterprise }[\ldots] \text { I am the } \\
\text { first to come and the } \\
\text { last to leave » }\end{array}$ \\
\hline C3-E3 & $\begin{array}{l}\text { Shared leadership } \\
\text { Point of view of an adherent } \\
\text { "With our president (Female), there is a relation of friendship before } \\
\text { being a professional relation }[\ldots] \text { we never had a conflict with her [...] } \\
\text { we work and can joke at ease. In addition, we feel more autonomous, we } \\
\text { participate in decision taking, and we care all of us about the cooperative } \\
\text { interests » }\end{array}$ & $\begin{array}{l}\text { Patience } \\
\text { "If people are patient in } \\
\text { what they do, they will } \\
\text { certainly succeed» }\end{array}$ \\
\hline
\end{tabular}

\section{Discussion and conclusion}

The obtained results at the end of the analysis of case studies show that enterprising success, according to the persons asked is distinguished by a major point. The principal distinction in social enterprising conception, psychologically; is the interest given by the interviewers and interviewees to the other and to oneself. This vision constitutes a clear dividing line between the social and the economic. In cooperatives where the aim is social, the interviewees look for the well-being of the other; while in the enterprises where the purpose is economic, the interviewees seek their own comfort.

In fact, the founders of cooperatives mobilize three themes to define enterprising success, such as (1) development of the province, (2) to satisfy the needs of the clients, (3) to satisfy the needs of the adherents. The latters are not attracted generally by personal success, but interested by collective or social success. Whereas the founders of the agricultural enterprises assimilate this enterprising success to (1) growth of their enterprises, to (2) the good financial situation, and to (3) achievement of objectives fixed at the beginning of the creation of their enterprise.

Moreover, the results of this analysis make also to the surface that external support of the cooperative is perceived as essential to its development and functioning. As we noticed, social and economic entrepreneurs share a similar response as far as the weight of this factor is concerned. Another fundamental factor of success is the feeling of belonging. The latter is seen via two aspects such as the feeling of belonging of women adherents, and fidelity of clients. In the same way, shared leadership comes as a determining factor of success because it involves all members of the cooperative in decision taking and responsibility for the future. Also, inherent factors of 
economic enterprising such as perseverance, patience are related to enterprising success. Success is determined not only by economic factors, but also by the social ones.

This essay of clarification of the notion of social enterprising success, is a phenomenon which is often kept in the shadows, constitute a modest contribution to the understanding of a very complex, very interesting, very large issue in the field of entrepreneurship. We remind the reader that the nature of the results of this research is exploratory and preliminary, and based on a limited number of cases. This observation aims to be an invitation to a necessary corroboration for future research. The value of this research is not limited only at the level of theory, but also useful to investigators, practitioners, and involved parties, by offering them some precise points of reference in order to understand a phenomenon which remains not very explored and studied. Thus, other points of reflexion need in-depth studies which can give more time to this research which is still at its embryonic stage. The extent of this research can be justified by its exploratory character. Our strategy for future research is to go deeply in to the present study at a higher level so that to determine the different key factors of success of social entrepreneurship. In fact, this present qualitative research, which is based on a number of limited cases, will encourage other empirical works in which we will adopt a mono-sector and multi-sector longitudinal qualitative study. The aim is to conceive a more detailed reading of the key factors of success in social entrepreneurship. To answer such ways of reflexion is certainly pertinent for actions of public powers as well as for involved parties devoted to the local and regional development.

\section{References}

Baumard, P., Donada, C., Ibert, J., \& Xuereb, J. M. 1999. « La collecte des données et la gestion de leurs sources », Dans Thietart R.A., (Coll.), Méthodes de recherche en management, Paris, Dunod, p.224-256.

Bchini, B. 2012. «Les coopératives agricoles entre recherche de viabilité et utilité sociale: le cas de la coopérative des semences en Tunisie "COSEM"», Maroc, 6ème Edition du Congrès International d'Economie et de Gestion:Entrepreneuriat et Management des Coopératives Regards Croisés, Ecole Nationale de Commerce de Gestion, Agadir, 11-12 Mai.

Bravo-Bouyssy, K. 2004. «Une mesure du succès de carrière chez le travailleur en solo », Actes du 15ème Congrès de l'AGRH. Montréal, Canada.

Brouard, F. 2006. « Social entrepreneurship : toward a better understanding of the concept ». Paper presented at the 23rd Annual Conference of the Canadian Council for Small Business and Entrepreneurship (CCSBE), Trois-Rivières, Canada, 28-30 septembre.

Bruyat, C. 1993. Création d'entreprise: contributions épistémologiques et modélisation. Thèse de Doctorat en Sciences de Gestion, Université Pierre Mendès France de Grenoble II, 431p

Capron, H., Cincra, M., Greunz, L., Lerminiaux, G., \& Lohest, O. 2009. Entrepreneuriat et création d'entreprises : Facteurs déterminants de l'esprit d'entreprise. Editions De Boek Université.

Carrier, C., Raymond, L., \& Eltaief, A. 2004. « Cyberentrepreneurship: A multiple case study ». International Journal of Entrepreneurial Behavior \& Research, vol.10, n5, p.349-363. https://doi.org/10.1108/13552550410554320.

Cheung, C., \& Chow, S. 2006. « An investigation of the success factors of young Chinese entrepreneurs in Hong Kong ». International Journal of Entrepreneurship, vol.10, p. 43-70. http://hdl.handle.net/10722/35912.

Cornuau, F. 2008. «Qui sont les entrepreneurs en France ? Et comment économistes et statisticiens se représententils ces personnes ? " Revue internationale de Psychosociologie, vol.XIV, n ${ }^{\circ}$, p.181-205. https://doi.org/10.3917/rips.032.0181.

Cukier, W., Trenholm, S., Carl, D., \& Gekas, G. 2011. «Social entrepreneurship: a content analysis ». Journal of Strategic Innovation and Sustainability, vol.7, n²1, p.99-119. DOI: 10.18178 / ijtef.2016.7.4.508.

Dahan, J. 2008. Succès individuel \& contexte stratégique: le cas des cadres intermédiaires. Thèse de Doctorat en Sciences de Gestion, Université de Montréal, HEC Montréal, 267p.

Danjou, I. 2002. «L'entrepreneuriat: un champ fertile à la recherche de son unité ». Revue française de gestion, n 138 , p.109-125. SSN 0338-4551, ZDB-ID 196286-3.

Dees, G., \& Anderson, B. B. 2006. « Framing a theory of social entrepreneurship: Building on two schools of practice and thought ». Business, vol.1, n³, p.39-66.

Deschamps, B., \& Geindre, S. 2009. « Reprise d'entreprise: risque et accompagnement ». XVIIIème conférence de l'Association Internationale de Management Stratégique (AIMS), Grenoble.

Fayolle, A. 2004a. "Compréhension mutuelle entre les créateurs d'entreprise et les accompagnateurs: une recherche exploratoire sur des différences de perception ». Management International, vol.8, ${ }^{\circ} 2$.

Fayolle, A. 2004b. " A la Recherche du Coeur de l'Entrepreneuriat: vers une nouvelle vision du domaine ». Revue internationale PME, vol.17, $\quad \mathrm{n}^{\circ} 1, \quad$ p.101-121. https://doi.org/10.7202/1008453ar.

Filion, L. J. 1997. "Le champ de l'entrepreneuriat: historique, évolution, tendances ». Cahier de recherche $n^{\circ}$ 97.01, HEC Montréal, 36 p. (www.hec.ca/chaire.entrepreneuriat). 
Filion, L. J. 2010. « le métier d'entrepreneur ». dans Filion, L.J et C. Ananou, (coll.), De l'intuition au projet d'entreprise, Éditions Transcontinental, Éditions de la Fondation de l'entrepreneurship et Presses HEC Montréal, Chap. 22, p.441- 456.

Filion, L. J., \& Borges, C. 2010a. « Dix conseils aux créateurs d'entreprises ». Cahier de recherche $n^{\circ} 2010-10$, Chaire d'entrepreneuriat Rogers-J.-A.-Bombardier, HEC Montréal. (www.hec.ca/chaire.entrepreneuriat).

Filion, L. J., \& Borges, C. 2010b. « La création d'entreprise: un processus complexe » dans Filion, L.J et C. Ananou, (coll.), De l'intuition au projet d'entreprise, Éditions Transcontinental, Éditions de la Fondation de l'entrepreneurship et Presses HEC Montréal, Chap.2, p.59-74.

Gagnon, Y. C. 2005. L'étude de cas comme méthode de recherche: guide de réalisation: Sainte-Foy : Presses de l'Université du Québec, 128p.

Gartner, W. B. 1988. "Who is an entrepreneur? Is the wrong question ». American journal of small business, vol.12, nº 4 p.11-32. DOI: 10.1177 / 104225878801200401 .

Hähnel, A. 2011. « Success factors and social entrepreneurship ». Oikos Young Scholars Entrepreneurship Academy, Institutions, Entrepreneurship and Organisational change.

Hernandez, É. M. 2001. L'entrepreneuriat: approche théorique: Editions L'Harmattan.

Lasch, F., Le Roy, F., \& Yami, S. 2005. « Les déterminants de la survie et de la croissance des start-up TIC ». Revue Française de Gestion, vol.31, n.155, p. 37-56. https://doi.org/10.3166/rfg.155.37-56.

Letts, C. W., Brown, L. D., \& Alvord, S. H. 2003. « Social Entrepreneurship: Leadership that Facilitates Societal Transformation-An Exploratory Study ». Centre for Public Leadership. Working Paper 5.

Levent, T. B., Masurel, E., \& Nijkamp, P. 2003. « Diversity in entrepreneurship: ethnic and female roles in urban economic life ». International journal of social economics, vol.30, $\mathrm{n}^{\circ} .11, \mathrm{p} .1131-1161$. https://doi.org/10.1108/03068290310497495.

Lévesque, B. 2002. «Entrepreneurship collectif et économie sociale : entreprendre autrement». Cahier de l'ARUC, $\mathrm{n}^{\circ} \mathrm{I}-02-2002$. Montréal

Lortie-Lussier, M., \& Rinfret, N. 2005. « Determinants of objective and subjective success of men and women ». International Review of Administrative Sciences, vol.71, n4, p. 607-624. https://doi.org/10.1177/0020852305059601.

Mair, J., \& Marti, I. 2004. « Social entrepreneurship: What are we talking about ? », A framework for future research. IESE Business School - University of Navarra.

Marchesnay, M. 1995. Management stratégique: Paris, Eyrolles Université, Collection, 200p.

Michaud, P. 2003. La course, comment les cadres talentueux font leur chemin dans la grande entreprise: Les Éditions Transcontinental inc.

Nabi, G. R. 1999. « An investigation into the differential profile of predictors of objective and subjective career success 》. Career Development International, vol.4, nº, p.212-225. https://doi.org/10.1108/13620439910270599.

Pavlovich, K., \& Corner, P. D. 2006. « Knowledge creation through co-entrepreneurship ». International Journal of Knowledge Management Studies, vol.1, n 1/2, p.178-197. https://doi.org/10.1504/IJKMS.2006.008852

Sammut, S. 1998. Jeune Entreprise. La phase cruciale du démarrage. Paris: L'Harmattan.

Sammut, S. 2001. "Processus de démarrage en petite entreprise: système de gestion et scénarios ». Revue de l'Entrepreneuriat, vol.1, $\mathrm{n}^{\circ} 1, \mathrm{p} .51-76$. https://doi.org/10.3917/entre.011.0061.

Shane, S., \& Venkataraman, S. 2000. «The promise of entrepreneurship as a field of research ». Academy of Management Review, vol.25, n¹, p.217-226. DOI: 10.2307 / 259271.

Sharir, M., \& Lerner, M. 2006. « Gauging the success of social ventures initiated by individual social entrepreneurs ». Journal of world business, vol.41, n 1, p. 6-20. https://doi.org/10.1016/j.jwb.2005.09.004.

Smida, A., \& Khelil, N. 2010. «Repenser l'échec entrepreneurial des nouvelles entreprises. Proposition d'une typologie basée sur une approche intégrative ». Revue Internationale PME, vol.23, $\mathrm{n}^{\circ} 2$. https://doi.org/10.7202/1005762ar.

Thiétart, R. A. 1999. Méthodes de recherche en management: Dunod, Paris.

Tounes, A., \& Fayolle, A. 2006. «L'odyssée d'un concept et les multiples figures de l'entrepreneur ». La Revue des Sciences de Gestion, vol.4, n²20-221, p.17-30. https://doi.org/10.3917/rsg.220.0017.

Usunier, J. C., Easterby-Smith, M., \& Thorpe, R. 1993. Introduction à la recherche en gestion. Paris: Economica.

Yin, R. K. 1994. « Discovering the future of the case study method in evaluation research ». Evaluation Practice, vol.15, n³, p. 283-290. https://doi.org/10.1016/0886-1633(94)90023-X.

Zafir, M. M., \& Fazilah, M. H. 2011. « Entrepreneurial Success: An Exploratory Study among Entrepreneurs ». International Journal of Business and Management, vol. 6, n²1, p.116-125. DOI: 10.5539 / ijbm.v6n1p116. 